\title{
INVESTIGATION OF PESTE DES PETITS RUMINANTS (PPR) OUTBREAK AMONG GOATS AND SHEEP OF AGASAVALLI VILLAGE (SHIVAMOGGA DISTRICT, KARNATAKA)
}

\author{
N. KARBASANAVAR, P. S. BAGAlAKOTE*, B. E. ShambUlingaPPA \\ K. J. ANANDA, S. P. SATHEESHA \\ B. KAVITHA RANI AND K. C. MALLINATH \\ Karnataka Veterinary, Animal and Fisheries Sciences University \\ Veterinary College, Shivamogga - 577204 \\ Karnataka, India
}

Peste des petits ruminants (PPR) is a highly contagious and economically important disease of small ruminants associated with high morbidity and mortality. Outbreak investigation was carried out in the month of August 2015 in goat and sheep of Agasavalli village (Shivamogga district, Karnataka). A total of 341 goats and 60 sheep reared under semi-intensive system were investigated for morbidity, mortality and case fatality. Affected animals exhibited symptoms suggestive of PPR viz. high fever, severe coughing, facial swelling, purulent nasal discharge, ulceration (gum, dental pad and oral commissure), profuse watery diarrhea with foul smell, anorexia and abortions in pregnant animals leading to death in about a week. Representative samples $(n=10)$ collected from ailing animals were analysed in the laboratory and post-mortem examination of dead animals were carried out. Lateral flow assay (serum) and polymerase chain reaction (PCR) of nasal swabs confirmed PPR virus infection as the cause of outbreak among sheep and goats. Morbidity, mortality and case fatality due to PPR during the outbreak were 76.5\%, $24.9 \%$ and $32.6 \%$ in goats and $55.0 \%, 5.0 \%$ and $9.1 \%$ in sheep, respectively. Severity of infection was higher among young animals compared to adults. Keeping in view high morbidity and mortality of PPR infection in small ruminants, proper prophylactic vaccination of small ruminants is advocated for the management of disease.

Key words: Goat, Lateral flow assay, Outbreak, PCR, Sheep

Peste des petits ruaminants (PPR) is one of the economically important viral diseases of small ruminants (goats and sheep). PPR is caused by a Morbilli (PPR) virus belonging to the family Paramyxoviridae.
Infection is characterized by pyrexia, sores in the mouth, diarrhoea, conjunctivitis, pneumonia and higher morbidity and mortalities. PPR is highly prevalent in the African and Asian countries; especially, in 
the Indian subcontinent (Shaila et al., 1996; Dhar et al., 2002; Singh et al., 2004; Kwiatek et al., 2011; Balamurugan et al., 2012). It occurs as an endemic disease among small ruminants in India and other parts of Asia; it causes huge economic loss to the farmers (Shaila et al., 1996; Kumar et al., 2001; Yener et al., 2004; Singh et al., 2004; Venkataramanan et al., 2005; Balamurugan et al., 2012). Since PPR outbreaks are common among Indian goat and sheep, farmers must follow adequate precautions so as to avoid severity of infection. Prophylactic vaccination, hygiene, sanitation and good managemental practices play key role in curtailing severity of disease. Present outbreak investigation describes laboratory confirmation of PPR virus, clinico-pathological observations, morbidity and mortality of PPR in goat and sheep, reared together under the semiintensive type of rearing system in a village.

\section{MATERIALS AND METHODS}

Outbreak description: Investigation was carried out in the month of August 2015 on affected goats and sheep reared together under semi-intensive type of system at Agasavalli village $\left(13.9101900^{\circ} \mathrm{N}\right.$; $75.5220000^{\circ} \mathrm{E}$ ) of Shivamogga district, Karnataka state. Information about flock, age, sex, morbidity, mortality and history of farm was recorded on 341 goats and 60 sheep.

Clinico-pathological observations: Clinical examination was carried out on all affected animals and post-mortem examination was performed on dead animals. Representative samples ( $\mathrm{n}=5$ each) viz., nasal swab (for PCR) and blood (for serology) were collected aseptically into sterile containers for ante-mortem diagnosis from ailing animals. Representative samples $(n=10)$ collected from dead animals were subjected for PCR confirmation of PPR virus.

Serum samples $(\mathrm{n}=10)$ were tested for PPR using lateral flow assay (PPRV Ab Rapid Detection Test Kit, Genomix ${ }^{\circledR}$ ) following manufacturer's instructions. Blood and nasal samples were subjected for confirmation using PCR as per the protocol of Forsyth and Barett (1995).

\section{RESULTS}

Morbidity, mortality and case fatality observed among different age groups during the outbreak are shown in Table 1. Out of 341 goats, $261(76.5 \%)$ were affected with PPR; morbidity of $100 \%$ and $56.5 \%$ was observed among kids and adult goats, respectively. Higher mortality of $34.4 \%$ was observed among young stock compared to the adult goats $(16.8 \%)$. Case fatality rate (CFR) of $34.4 \%$ was observed in young; while, $29.8 \%$ CFR was observed in adult goats and overall CFR for goats was $32.6 \%$.

Among the sheep, out of 60 animals observed, $33(55 \%)$ were affected with PPR. Morbidity was higher among young animals 23 (79.3\%) compared to adults 10 $(32.2 \%)$. Mortality among young sheep was observed at $10.3 \%$ with no mortality in adult sheep. Case fatality rate was $13 \%$ in young sheep; however, overall CFR was $9.1 \%$ among the sheep. 
PPR outbreak among sheep and goats

Table 1. Morbidity, mortality and case fatality in goats and sheep during PPR outbreak

\begin{tabular}{|c|c|c|c|c|c|c|}
\hline Species & $\begin{array}{l}\text { Age } \\
\text { group }\end{array}$ & $\begin{array}{l}\text { Group } \\
\text { size }\end{array}$ & $\begin{array}{c}\text { Vaccination } \\
\text { history }\end{array}$ & Morbidity & Mortality & $\begin{array}{c}\text { Case } \\
\text { fatality } \\
\text { rate } \\
\end{array}$ \\
\hline \multirow[t]{2}{*}{ Goat } & $\begin{array}{c}\text { Young } \\
(<18 \text { months })\end{array}$ & 157 & No & $157(100 \%)$ & $54(34.4 \%)$ & $34.4 \%$ \\
\hline & $\begin{array}{c}\text { Adult } \\
(>18 \text { months })\end{array}$ & 184 & No & $104(56.5 \%)$ & $31(16.8 \%)$ & $29.8 \%$ \\
\hline Total & & 341 & - & $261(76.5 \%)$ & $85(24.9 \%)$ & $32.6 \%$ \\
\hline \multirow[t]{2}{*}{ Sheep } & $\begin{array}{c}\text { Young } \\
(<18 \text { months })\end{array}$ & 29 & No & $23(79.3 \%)$ & $3(10.3 \%)$ & $13 \%$ \\
\hline & $\begin{array}{c}\text { Adult } \\
(>18 \text { months })\end{array}$ & 31 & Yes & $10(32.2 \%)$ & 0 & 0 \\
\hline Total & & 60 & - & $33(55 \%)$ & $3(5 \%)$ & $9.1 \%$ \\
\hline
\end{tabular}

Clinical examination of affected goat and sheep showed high fever, coughing, respiratory signs, facial swelling, purulent nasal discharge, ulceration (gum, dental pad and oral commissure), erosive lesions (inner side of upper lip), diarrhea (profuse watery feces with foul smell), lameness, off-fed, red colored urine, lesions around eyes and abortions among pregnant does (Fig. 1).

Pathological findings revealed oral erosions with bran-like deposits (erosive stomatitis). Nasal catarrhal discharge and severe congestive/ hemorrhagic lesions on the tracheal mucosa were observed in affected animals. Fibrinous deposits were evident over the pleura and pericardium; mild pneumonia was also evident in lungs. Subepicardial and sub-endocardial haemorrhages were found over the heart. Congestion of cortico-medullary junction of kidneys was observed. Mesenteric lymph nodes showed extensive congestion and enlargement. Large intestine showed mucosal erosions accompanied with hemorrhagic lesions. Haemorrhages were also evident on the mucosal surface of abomasum.

Serum samples tested positive for PPR Virus antibodies by Lateral flow assay (PPR kit) in the laboratory of Department of Veterinary Public Health \& Epidemiology, Veterinary College Shivamogga. The blood and nasal swabs found positive for PPR by polymerase chain reaction analysis yielded expected amplicon size of 371 bp (Fig. 2).

\section{DISCUSSION}

PPR is one of the serious viral diseases of small ruminants. Frequent outbreaks of PPR have been reported in several countries. 
Clinico-pathological findings although lead to indicative diagnosis of PPR among small ruminants in endemic areas; nevertheless, laboratory confirmation is of critical significance for confirmation of the infection. In the present study, PPR outbreak was suspected in goats and sheep based on clinico-pathological findings that was later confirmed by laboratory diagnosis using serology and PCR; such diagnostic approach is routinely used for outbreak investigation (Kumar et al., 2001; Mirza et al., 2008; Zahur et al., 2009; El-Yuguda et al., 2009; Ali et al., 2014).

Present investigation showed $76.5 \%$ and $55 \%$ morbidity in goats and sheep, respectively; these observations were in concordance with other investigators (Mirza et al., 2008; Rashid et al., 2008; Zahur et al., 2009). In a similar study, Chowdhury et al. (2014) reported morbidity of $75 \%$ (63\% to $100 \%)$ in Bengal goats in India.

Mortality due to PPR in the present investigation was higher among goats (24.9\%) compared to sheep (5\%) indicating higher susceptibility of goats than the sheep; this observation was in corroboration with Abubakar et al. (2008) and Zahur et al. (2014).

In the present investigation, higher susceptibility to PPR was found among young animals (morbidity, mortality and case fatality rate) than the adults; this observation was in accordance with Kumar et al. (2001) and Zahur et al. (2009). Similar findings were also made by Kulkarni et al. (1996); where, significantly higher case fatality was observed among kids.

Clinico-pathological findings of PPR outbreak observed in the present investigation were in accordance with observations of Mirza et al. (2008), Zahur et al. (2009) and El-Yuguda et al. (2009).

PPR virus antibodies were detected in serum using lateral flow assay for the rapid diagnosis of PPR; such tests aid in the rapid detection of virus not only in the laboratory but also at the field level. PCR-based confirmatory diagnosis of PPR virus made in this study was also followed by other authors (Couacy-Hymann et al., 2002; Balamurugan et al., 2006; Ali et al., 2014).

Higher morbidity and mortality due to PPR was observed in goats than the sheep, this might be probably due to vaccination of the later. Nevertheless, lack of awareness among farmers about vaccination, selective immunization of only productive animals, ignorance towards acceptability of modern technologies, etc. render flocks unprotected against such economically important but preventable diseases of small ruminants.

Conflict of interest: Authors declare that there is no conflict of interest regarding the present research work. 
Indian Journal of Animal Health, December, 2018

PPR outbreak among sheep and goats

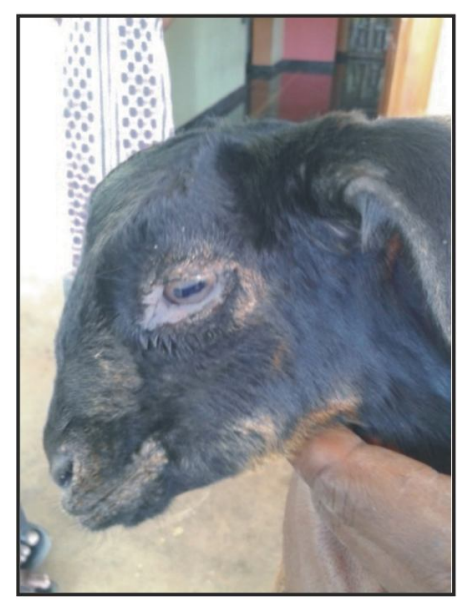

a. Lesions around eyes

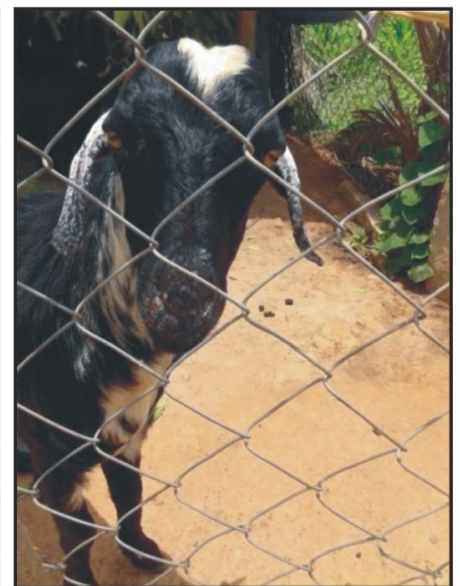

b. Purulent nasal discharge

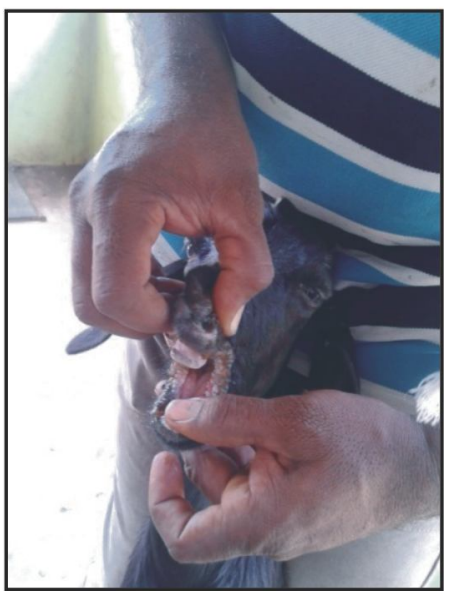

c. Ulceration of gum and dental pad

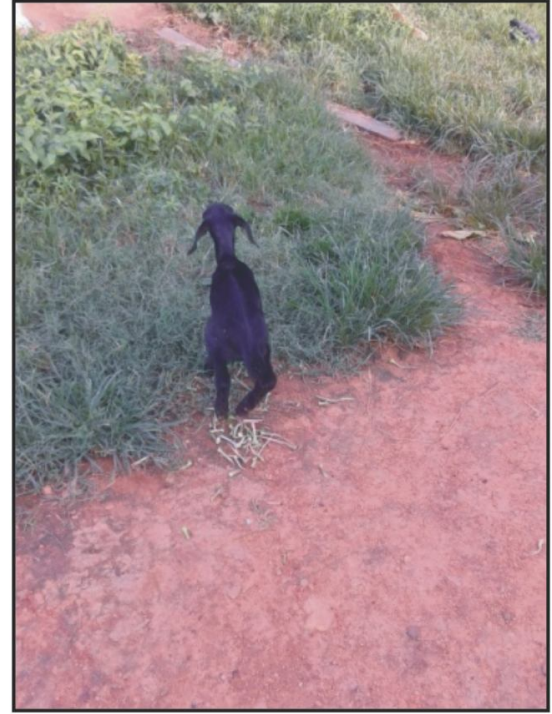

d. Lameness

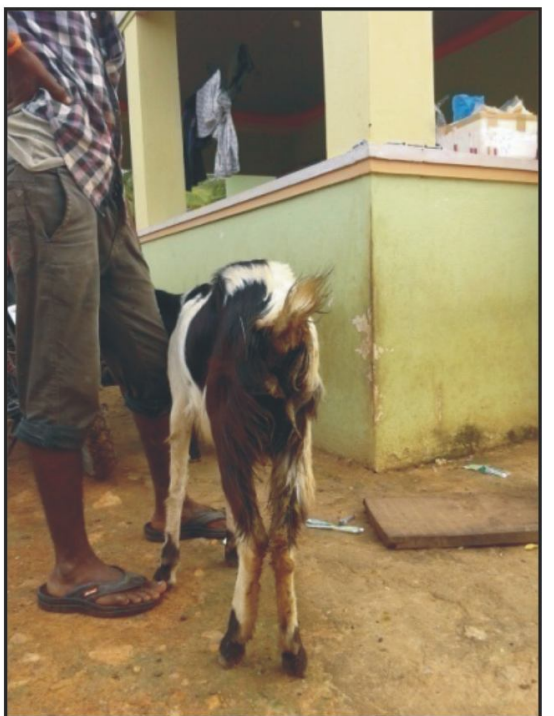

e. Profuse watery diarrhoea

Fig. 1. Clinico-pathological observations in affected goats 
Indian Journal of Animal Health, December, 2018

PPR outbreak among sheep and goats

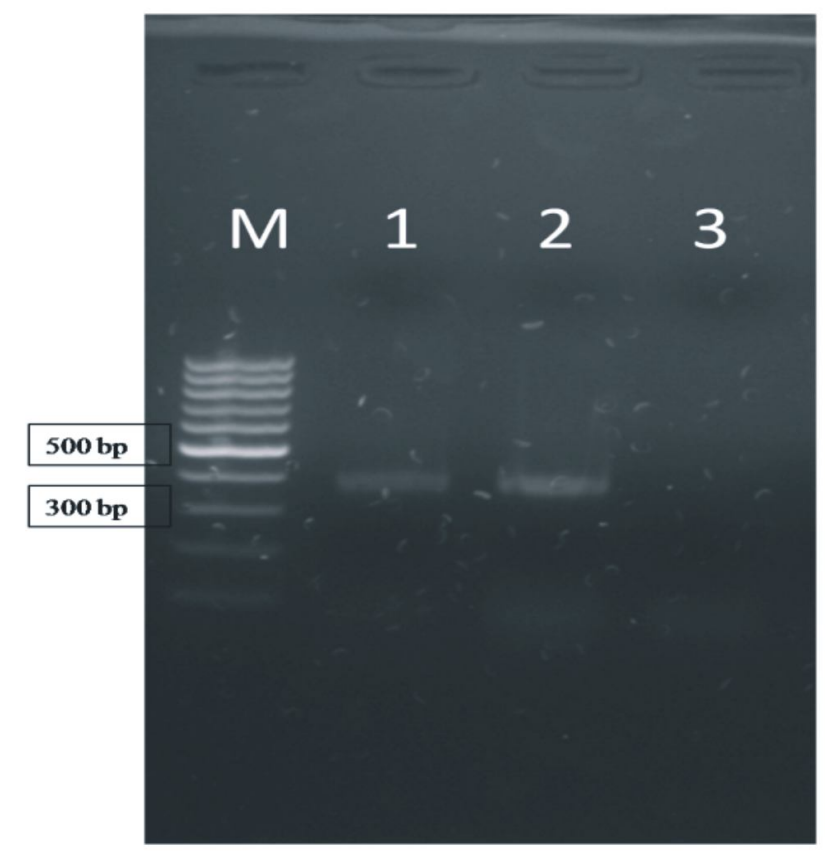

Lane M- 100 bp Ladder; Lane 1- Sample 1; Lane 2- Sample 2;

Lane 3- No template control

Fig. 2. PCR detection of PPR using primer sets F1 \& F2 (PPR virus specific amplicon of $371 \mathrm{bp}$ ) 


\section{REFERENCES}

Abubakar M, Jamal SM, Hussain M and Ali Q, 2008. Incidence of Peste des petits ruminants (PPR) virus in sheep and goats as detected by Immuno-capture ELISA (Ic ELISA). Small Ruminant Res, 75: 256-259

Ali YH, Intisar KS and Khalafalla AI, 2014. Outbreaks of Peste des petits ruminants in two different localities in Sudan. J Vet Med Ani Hlth, 6(6):174-177

Balamurugan V, Saravanan P, Sen A, Rajak KK and Venkatesan G et al., 2012. Prevalence of Peste des petits ruminants among sheep and goats in India. J Vet Sci, 13(3): 279-285

Balamurugan V, Sen A, Saravanan P, Singh RP and Singh RK et al., 2006. One-step Multiplex RT-PCR Assay for the detection of Peste des petits ruminants virus in clinical samples. Vet Res Communications, 30(6): 655-666

Chowdhury EH, Bhuiyan AR, Rahman MM, Siddique MSA and Islam MR, 2014. Natural Peste des petits ruminants virus infection in Black Bengal goats: virological, pathological and immunohistochemical investigation. BMC Vet Res, 10: 263

Couacy-Hymann E, Roger F, Roger F, Hurard C and Guillou JP et al., 2002. Rapid and sensitive detection of Peste des petits ruminants virus by a polymerase chain reaction assay. J Virol Methods, 100(12): $17-25$
Dhar P, Sreenivasa BP, Barrett T, Corteyn M and Singh RP et al., 2002. Recent epidemiology of Peste des petits ruminants virus (PPRV). Vet Microbiol, 88: $153-159$

El-Yuguda AD, Abubakar MB, Nabi AB, Andrew A and Baba SS, 2009. Outbreak of Peste des petits Ruminants in an unvaccinated Sahel Goat Farm in Maiduguri, Nigeria. African J Biomed Res, 12(1): 83-87

Forsyth M and Barrett T, 1995. Detection and differentiation of Rinder pest and Peste des petits ruminants viruses in diagnostic and experimental samples by polymerase chain reaction using $\mathrm{P}$ and $F$ gene-specific primers. Virus Res, 39: 151-163

Kulkarni DD, Bhikane AU, Shaila MS, Varalakshmi P and Apte MP et al., 1996. Peste des petits ruminants in goats in India. Vet Rec, 138: 187-188

Kumar A, Singh SV, Rann R, Aid RKV and Misrp J et al., 2001. PPR outbreak in goats: Epidemiological and therapeutic studies. Indian J Anim Sci, 71(9): 815818

Kwiatek O, Ali YH, Saeed IK, Khalafalla AI and Mohamed OI et al., 2011. Asian lineage of Peste des petits ruminants virus, Africa. Emerg Infect Dis, 17: 1223-1231

Mirza AK, Hussain SN, Bahadar S, Ali A and Shah IA, 2008. An outbreak of Peste des 
petits ruminants (PPR) in goats in district Chitral, N.W.F.P., Pakistan. ARPN J Agri Biolo Sci, 3: 19-22

Rashid A, Asim M and Hussain A, 2008. An Outbreak of Peste des petits ruminants in goats at district Lahore. J Anim Pl Sci, 18: $72-75$

Shaila MS, Shamaki D, Forsyth MA, Diallo A and Goatley L et al., 1996. Geographic distribution and epidemiology of Peste des petits ruminants viruses. Virus Res, 43: $149-153$

Singh RP, Saravanan P, Sreenivasa BP, Singh RK and Bandyopadhyay SK, 2004. Prevalence and distribution of Peste des petits ruminants virus infection in small ruminants in India. Rev Sci Tech, 23: 807-819

Venkataramanan R, Bandyopadhyay SK and Oberoi MS, 2005. Present status and strategies for the control of transboundary and other economically important animal diseases in India: a review. Indian J Anim Sci, 75: 456-464

Yener Z, Saðlam YS, Temur A and Kelep H, 2004. Immunohistological detection of Peste des petits ruminants viral antigens in tissues from cases of naturally occurring pneumonia in goats. Small Ruminant Res, 51: 273-277

Zahur AB, Ullah A, Irshad H, Farooq MS and Hussain M et al., 2009. Epidemiological investigations of a Peste des petits ruminants (PPR): Outbreak in afghan sheep in Pakistan. Pakistan Vet J, 29(4): 174-178

Zahur AB, Ullah A, Irshad H, Latif A and Ullah RW et al., 2014. Epidemiological analysis of Peste des petits ruminants (PPR) outbreaks in Pakistan. J Biosci Med, 2: 18-26 